\title{
Non-linear properties of supercooled liquids in the system $\mathrm{Na}_{2} \mathrm{O}-\mathrm{SiO}_{2}$
}

\author{
R. Knoche ${ }^{\alpha}$, D.B. Dingwell, F.A. Seifert, S.L. Webb \\ Bayerisches Geoinstitut, Universität Bayreuth, D-95440 Bayreuth, Germany
}

(Received July 30, 1993; revised and accepted January 27, 1994)

\begin{abstract}
The physical properties, viscosity, density, heat capacity and thermal expansivity, of relaxed supercooled liquids in the temperature range just above the glass transition have been determined for ten compositions along the compositional binary $\mathrm{Na}_{2} \mathrm{O}-\mathrm{SiO}_{2}$, in the range of $2-45 \mathrm{~mole} \% \mathrm{Na}_{2} \mathrm{O}$, by a combination of scanning calorimetry, dilatometry and micropenetration viscometry. The viscosity, density, heat capacity and thermal expansivity in the glassy state have also been determined.

The heat capacities illustrate a linear composition dependence for the glassy state and a smooth but strongly non-linear composition dependence for the supercooled liquid state. The thermal expansivities were determined by dilatometry up to the glass transition and, by a normalized comparison of relaxation behavior in the glass transition interval, to temperatures $\sim 50^{\circ} \mathrm{C}$ above the glass transition. The expansivity is a linear function of the molar composition in the glass but a strongly non-linear function of molar composition in the supercooled liquid.

The viscosity data just above the glass transition temperature, combined with data from high temperature using the concentric cylinder method, illustrate that the composition dependence of viscosity is strongly non-linear and exhibits an inflection as a function of composition. The glass transition temperature, taken as the peak temperature of the calorimetric measurements, is not in general an isokom in this system.

The data for these property determinations in the $\mathrm{Na}_{2} \mathrm{O}-\mathrm{SiO}_{2}$ system provide much improved constraints on the partial molar properties of $\mathrm{SiO}_{2}$ liquid and partial molar properties of the $\mathrm{SiO}_{2}$ component in silicate melts. The complex behavior of the transport properties, i.e. the glass transition temperature and the viscosity, point to complexities in viscous flow beyond that of simple binary mixing of the $\mathrm{Na}_{2} \mathrm{O}$ and $\mathrm{SiO}_{2}$ components.
\end{abstract}

\section{Introduction}

The physical properties of silicate glasses and melts are of central importance in material science and geoscience. For an understanding of magmatic processes and the development of general models of igneous petrogenesis the temper-

[CA]

${ }^{\alpha}$ Present address: Department of Geology, University of Alberta, Edmonton, Alta. T6G 2E3, Canada. ature- and pressure-dependent properties of silicate melts are essential.

Under appropriate conditions crystallization may be avoided in many silicate melts down to subliquidus temperatures. Such melts vitrify over a temperature range quite distinct from the crystallization temperature; in a temperature range termed the glass transition $\left(T_{\mathrm{g}}\right)$ region. At temperatures just above the glass transition, silicate melts may be studied as supercooled liquids (i.e. liquids that are in local or metastable equilib- 
rium ) provided the temperatures and time scales of measurement exclude crystallization or liquid-liquid unmixing (Dingwell and Webb, 1990). These low-temperature data can often be determined more precisely than their high-temperature counterparts. Additionally, in combination with high-temperature data for the stable liquid such low-temperature data provide a very wide $\left(\sim 1000^{\circ} \mathrm{C}\right)$ temperature range over which the behavior of individual properties can be interpolated (Knoche et al., 1992a). Studies of the physical properties of supercooled liquids thus provide a much more complete picture of the temperature- and composition dependence of liquid structure and properties and qualitatively new pictures of the relationship between structure and properties have emerged as a result ( $\mathrm{Ri}$ chet, 1984). Finally, the glass transition occurs for dry silicic melts in a temperature range that is relevant to the crystallization of magmatic systems. Thus property determinations near $T_{\mathrm{g}}$ can be applied to the calculation of melt properties during igneous petrogenesis without extrapolation from higher temperature (Dingwell, 1993).

Despite the theoretical advantages of including low-temperature property determinations in the database for the equation of state of silicate melts, a number of practical challenges remain. These challenges have meant that the selection of existing supercooled liquid property data from the literature is difficult (Bansal and Doremus, 1986). For example, the composition dependence of melt transport properties is increasingly sensitive to melt composition at decreasing temperatures. Thus the quality of chemical characterization and purity and homogeneity of samples plays a decisive role in determining the accuracy with which low-temperature data for supercooled liquids can be integrated into the database.

The system $\mathrm{Na}_{2} \mathrm{O}-\mathrm{SiO}_{2}$ is a case in point. Although widely separated in composition from either natural melts or those of industrial interest, this system represents a simple model for the variation in melt properties and structure to be expected in natural and industrial melts resulting from a variation in the fraction of the network-forming cation $\mathrm{Si}$. It has accordingly been extensively investigated in both the super- and subliquidus regimes. Data exist in the literature for several physical properties of interest. Despite this and for some of the reasons mentioned above, a number of controversies surround the properties of melts in this simple system. These controversies have implications that go far beyond the simple system. For example, the isothermal composition dependence of viscosity (isokom) may or may not contain inflections. The glass transition temperature (peak temperature) may or may not represent an isokom. The partial molar volumes may or may not be compositionally independent. The expansivity of melts may or may not equal zero in $\mathrm{SiO}_{2}$-rich compositions, and the heat capacities may or may not be additive. The present investigation of very well-characterized melts in the $\mathrm{Na}_{2} \mathrm{O}-\mathrm{SiO}_{2}$ system answers the questions posed by the above statements and in doing so sets the stage for further high-precision studies of the composition dependence of these melt properties.

\section{Methods}

Ten samples in the $\mathrm{Na}_{2} \mathrm{O}-\mathrm{SiO}_{2}$ system were synthesized, one with $98 \mathrm{~mole} \% \mathrm{SiO}_{2}$ and the other nine samples ranging from 95 to $55 \mathrm{~mole} \%$ $\mathrm{SiO}_{2}$ at intervals of $5 \mathrm{~mole} \%$. This compositional range was chosen to avoid synthesis problems for the amounts of material required for the present experiments. Melts with $>45$ mole $\% \mathrm{Na}_{2} \mathrm{O}$ could not be quenched to glasses in sufficient amounts, and melts with $<2$ mole $\% \mathrm{Na}_{2} \mathrm{O}$ have viscosities too high for homogenization.

Starting materials were $\mathrm{Na}_{2} \mathrm{CO}_{3}(99.9 \%)$ and $\mathrm{SiO}_{2}(99.995 \%)$. The $\mathrm{Na}_{2} \mathrm{CO}_{3}$ was dried overnight in a vacuum furnace at $220^{\circ} \mathrm{C}$, the $\mathrm{SiO}_{2}$ powder was weighed in immediately after opening the sealed aluminum package. The chemicals were weighed directly into plastic polyethylene bottles in amounts equivalent to $100 \mathrm{~g}$ of decarbonated melt and were roughly homogenized by agitation for $\sim 15 \mathrm{~min}$. The mixtures were then melted stepwise into a $75-\mathrm{cm}^{3}$ thin-walled $\mathrm{Pt}$ crucible at superliquidus temperatures. The products of these fusions were rich in bubbles. 
The melts were stirred with a $\mathrm{Pt}_{80} \mathrm{Rh}_{20}$ spindle until they were homogeneous and bubble free. Finally, the melts were allowed to cool to room temperature at a rate of several degrees per minute. The results were bubble- and crystal-free glasses. The homogeneity of the glasses was checked with the electron microprobe using a 10$\mu \mathrm{m}$ spot size. Within the spatial resolution of the electron microprobe no inhomogeneity was detected.

Due to the volatility of the $\mathrm{Na}$ under the microprobe analytical conditions, the bulk composition of the samples was determined by a separate bulk analytical method, inductively coupled plasma atomic emission spectroscopy (ICPAES ). Water content was determined by KarlFischer titration. The results of these analyses are listed in Table 1. The basis for all subsequent calculations and discussions of partial molar properties are the measured compositions of the samples. The analysis of the glasses by Karl-Fischer titration showed an increasing $\mathrm{H}_{2} \mathrm{O}$ content with increasing content of $\mathrm{Na}_{2} \mathrm{O}$ of the samples. The maximum water content observed was $0.15 \mathrm{wt} \%$ in the sample with 45 mole $\% \mathrm{Na}_{2} \mathrm{O}$.

Cylinders required for the dilatometer, calorimeter and micropenetration measurements were drilled from the glasses in the $\mathrm{Pt}$ crucibles with a diamond corer. For the high-temperature measurements of viscosity and density the rest

Table 1

Chemical composition and water content of the glasses

\begin{tabular}{|c|c|c|c|c|c|}
\hline & \multicolumn{3}{|c|}{$(w t \%)$} & \multicolumn{2}{|c|}{$($ mole $\%)$} \\
\hline & $\mathrm{SiO}_{2}$ & $\mathrm{Na}_{2} \mathrm{O}$ & $\mathrm{H}_{2} \mathrm{O}$ & $\mathrm{SiO}_{2}$ & $\mathrm{Na}_{2} \mathrm{O}$ \\
\hline 2 mole $\% \mathrm{Na}_{2} \mathrm{O}$ & 98.0 & 2.0 & 0.02 & 98.1 & 1.9 \\
\hline 5 mole $\% \mathrm{Na}_{2} \mathrm{O}$ & 95.0 & 5.0 & 0.03 & 95.1 & 4.9 \\
\hline 10 mole $\% \mathrm{Na}_{2} \mathrm{O}$ & 89.1 & 10.9 & 0.05 & 89.4 & 10.6 \\
\hline 15 mole $\% \mathrm{Na}_{2} \mathrm{O}$ & 83.6 & 16.4 & 0.04 & 84.0 & 16.0 \\
\hline 20 mole $\% \mathrm{Na}_{2} \mathrm{O}$ & 79.3 & 20.7 & 0.05 & 79.8 & 20.2 \\
\hline 25 mole $\% \mathrm{Na}_{2} \mathrm{O}$ & 73.7 & 26.3 & 0.03 & 74.3 & 25.7 \\
\hline 30 mole $\% \mathrm{Na}_{2} \mathrm{O}$ & 68.9 & 31.1 & 0.06 & 69.6 & 30.4 \\
\hline 35 mole $\% \mathrm{Na}_{2} \mathrm{O}$ & 64.0 & 36.0 & 0.09 & 64.7 & 35.3 \\
\hline $40 \mathrm{~mole} \% \mathrm{Na}_{2} \mathrm{O}$ & 59.0 & 41.0 & 0.10 & 59.8 & 40.2 \\
\hline $45 \mathrm{~mole} \% \mathrm{Na}_{2} \mathrm{O}$ & 54.2 & 45.8 & 0.15 & 55.0 & 45.0 \\
\hline
\end{tabular}

Analyzed by ICP-AES (average of 2 measurements), water content determined by Karl-Fischer titration. of the sample was remelted into the crucible used for the measurement at temperatures not higher than the original fusion temperature and stirred again until bubble free. All samples were stored in a desiccator until use in the experiments. After the high-temperature measurements the compositions of the samples were reanalyzed to check for changes in composition due to $\mathrm{Na}$ volatilization. No changes in composition could be observed within the error of the ICP-AES measurements.

At the low temperatures of the dilatometric, calorimetric and micropenetration measurements volatilization of $\mathrm{Na}$ is not to be expected due to the very high viscosities even at maximum experimental temperatures. During the low-temperature experiments the samples were constantly flushed by an argon gas flow. Thus incorporation of water was not anticipated. To check this assumption the sample with 45 mole\% $\mathrm{Na}_{2} \mathrm{O}$ was reanalyzed after the low-temperature measurements. This sample with the highest hygroscopy and $\mathrm{Na}$ volatility did not show any change in composition or water content. Therefore, the assumption of an unchanged composition of the samples after the low-temperature measurements can be made. None of the samples exhibited crystallization after the dilatometric or calorimetric measurements. For the micropenetration measurements the excursion (the time-temperature path) above the glass transition is somewhat greater than for the scanning calorimetric and dilatometric experiments. Here crystallization occurred for some samples. Only data from samples which did not show any evidence of crystallization during or after the micropenetration experiments were used.

\subsection{Heat capacity measurements}

The determination of the heat capacity of the glasses and supercooled liquids was performed on glass cylinders with a diameter of $6.4 \mathrm{~mm}$ and a length of $10 \mathrm{~mm}$ in a differential scanning calorimeter (DSC $111^{\circledR}$, Setaram). During the experiments the samples were heated at a constant rate of $5^{\circ} \mathrm{C} \mathrm{min}^{-1}$ up to the relaxed liquid (50$100^{\circ} \mathrm{C}$ above the glass transition temperature). 
Before the measurements the glasses had been cooled with rates of $1^{\circ}, 2^{\circ}, 5^{\circ}$ and $10^{\circ} \mathrm{C} \mathrm{min}^{-1}$ from the relaxed liquid. As a result, a set of four measurements was obtained for each glass. The calorimeter is calibrated regularly against a cylinder of sapphire with the same dimensions as the samples. The heat capacity data for sapphire were taken from Robie et al. (1979). Based on the measured sapphire heat capacity and the reproducibility of the measured heat capacities for the glasses, the error in the present heat capacity data is $\pm 1 \%$.

\subsection{Measurements of the molar volume and the thermal expansivity}

The density of the glasses at room temperature was determined with the Archimedean buoyancy method in toluene and air. From this and the chemical analyses of the glasses, the molar volume at room temperature was calculated. The measurements were performed on the same glass cylinders used for the dilatometry and calorimetry experiments. Prior to the density measurement these cylinders were cooled from the relaxed liquid with a rate of $5^{\circ} \mathrm{C} \mathrm{min}^{-1}$, permitting an exact comparison of the density data with the expansivity data obtained from the dilatometer and calorimeter data. The density method was calibrated against the densities of $\mathrm{Fe}$, Ir and $\mathrm{Pt}$, yielding an accuracy of $\pm 0.2 \%$.

The thermal expansivity of the glasses was measured in a vertical push-rod quartz glass dilatometer (TMA 402 ${ }^{\circledR}$, Netzsch) in continuous scanning mode on the same cylinders and with the same heating and cooling rates used in the calorimetry experiments. The dilatometer has been calibrated against the thermal expansivity of a sapphire single crystal (NBS sheet 732). This calibration, together with the reproducibility of the measured thermal expansion of the glasses results in an accuracy of $\pm 3 \%$ for the molar expansivities.

In the supercooled liquid the expansivity and the molar volume was calculated from the dilatometer trace through the glass transition in combination with the calorimeter trace obtained on exactly the same sample under identical ex- perimental conditions (i.e. same cooling history and same heating rate). This method of calculation for the expansivity of a supercooled liquid at temperatures just above the glass transition is based on the equivalence of the relaxation of enthalpy and volume in the glass transition interval. The theory and applicability of the method are described in detail in Knoche et al. (1992a, b, c) and Webb et al. (1992). The molar expansivities determined by this calculation have a maximum error of $\pm 5 \%$.

\subsection{Determination of the glass transition temperature}

A glass transition temperature $\left(T_{\mathrm{g}}\right)$ was determined from the scanning calorimeter and dilatometer curves. These curves show a peak which is characteristic for the glass transition. $T_{\mathrm{g}}$ was assigned to be the peak temperature of the $c_{p}$ and $\mathrm{d} V / \mathrm{d} T$ curves. The error in the glass transition temperature, so determined, is $\pm 3^{\circ} \mathrm{C}$ at $1 \sigma$ based on four measurements each using calorimetry and dilatometry. Different cooling rates lead to a freezing of the structure at different temperatures and therefore to a shift of the glass transition temperature. The influence of the cooling rate on the peak temperature is, however, very small if a constant heating rate is used (e.g., Zallen, 1983).

In this study we used the four different cooling rates principally to check the measurements for their reproducibility and thus increase the precision of the measurements. Although the peak height is influenced strongly by the cooling rate the thermal expansivity of the supercooled liquid should be identical and independent of the cooling rate as the liquid is completely relaxed. This was confirmed by the present measurements.

\subsection{Viscosity measurements}

The viscosity of the melts was determined using two different techniques. At low temperatures and therefore high viscosities a micropenetration technique was employed (in argon). The micropenetration measurements were per- 
formed in the same dilatometer used for the expansivity measurements of the glasses. This technique yields absolute viscosities and has been checked against the viscosity of NBS 711 glass. It has been demonstrated that, over the range of $10^{9}-10^{11} \mathrm{~Pa} \mathrm{~s}$, viscosity can be determined with an accuracy of $\pm 0.1 \log _{10} P$ a s. Details regarding the theory for the micropenetration technique can be found in Dingwell et al. (1992, 1993).

The shear viscosities of the stable liquids at high temperatures were determined using the concentric cylinder technique in equilibrium with air. The furnace, the setup and the computer interface together with the exact procedure and calibration are described by Dingwell and Virgo (1988) and Dingwell (1989a, b, 1990). With this technique a temperature range from $800^{\circ}$ to $1650^{\circ} \mathrm{C}$ and a viscosity range from $10^{\circ}$ to $10^{5} \mathrm{~Pa}$ $s$ can be covered. The measured viscosities are relative. The viscometer is regularly calibrated against a standard glass from the U.S. National Bureau of Standards (SRM 711). The accuracy of the measurements can be determined within $\pm 0.05 \log _{10}$ Pa s. The viscosity of each sample was measured at different temperatures after thermal equilibrium was reached. All observed viscosities were Newtonian, i.e. strain-rate independent.

\section{Results and discussion}

\subsection{Heat capacity}

The heat capacities of the glasses and supercooled liquids studied are presented in Fig. 1 and listed in Table 2 . Within the accuracy of the measurement the heat capacities of the glasses do not depend on the thermal history (see also Richet and Bottinga, 1986). The peak height changes drastically with changes in the previous cooling rate. The relaxed heat capacities of the supercooled liquids are, as expected, independent of cooling and heating rate. At a common cooling and heating rate the isothermal heat capacities as well as the peak height of the $c_{p}$ curves increase with increasing $\mathrm{Na}_{2} \mathrm{O}$ content of the

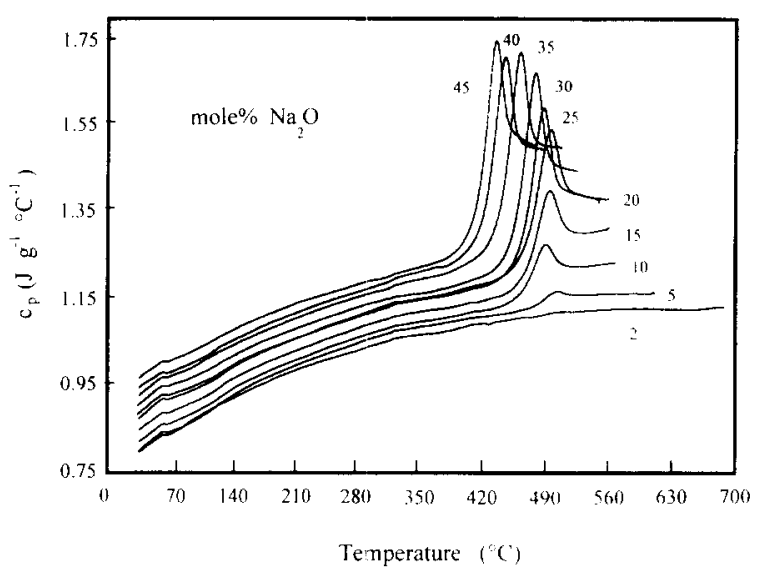

Fig. 1. Heat capacity curves of the glasses and supercooled liquids in the $\mathrm{Na}_{2} \mathrm{O}-\mathrm{SiO}_{2}$ system obtained from scanning calorimetry. The glasses were heated with a rate of $5^{\circ} \mathrm{C} \mathrm{min}-1$ after having previously been cooled from the liquid with $1^{\circ} \mathrm{C}$ $\mathrm{min}^{-1}$. (The small peak in all curves at $\sim 60^{\circ} \mathrm{C}$ is due to an irregularity in the background measurement.)

samples whereas the peak temperature decreases (Fig. 1).

Up to $400^{\circ} \mathrm{C}$ all samples studied are still in the glassy state. The isothermal heat capacities measured below this temperature depend linearly on composition in accordance with literature data and models for the heat capacities of glasses (Stebbins et al., 1984; Richet and Bottinga, 1986; Richet, 1987; Fig. 2). At $550^{\circ} \mathrm{C}$ all samples are in the supercooled liquid state (for the Na-rich samples the heat capacity was extrapolated up to $550^{\circ} \mathrm{C}$ as the onset of crystallization prevented its measurement up to this temperature). The relaxed isothermal heat capacities show a clearly non-linear dependence on composition (Fig. 2: note that conversion to molar heat capacities does not significantly change this conclusion and that the molar $C_{p}$-values are therefore also nonlinear).

Available heat capacity data for the $\mathrm{Na}_{2} \mathrm{O}-\mathrm{SiO}_{2}$ system are summarized in Mazurin et al. (1983), Richet et al. (1984), and Bansal and Doremus (1986). The results of the present study are consistent with literature data within the same temperature interval. The differences in heat capacity observed across the glass transition temperature are consistent with the data of Moynihan et al. (1976) and Bershtein et al. (1980). 
Table 2

Heat capacity $c_{p}\left(\mathrm{~J} \mathrm{~g}^{-1}{ }^{\circ} \mathrm{C}^{-1}\right)$ for the glasses and supercooled melts and glass transition temperature $T_{\mathrm{g}}\left({ }^{\circ} \mathrm{C}\right)\left(\mathrm{cooling}\right.$ rate: $1^{\circ} \mathrm{C}$ $\min ^{-1} /$ heating rate: $5^{\circ} \mathrm{C}_{\mathrm{min}^{-1}}$ )

\begin{tabular}{|c|c|c|c|c|c|c|c|c|c|c|}
\hline \multirow{2}{*}{$\begin{array}{l}T \\
\left({ }^{\circ} \mathrm{C}\right)\end{array}$} & \multicolumn{10}{|c|}{ mole $\% \mathrm{Na}_{2} \mathrm{O}$} \\
\hline & 2 & 5 & 10 & 15 & 20 & 25 & 30 & 35 & 40 & 45 \\
\hline 30 & 0.76 & 0.76 & 0.78 & 0.81 & 0.84 & 0.85 & 0.87 & 0.89 & 0.91 & 0.93 \\
\hline 40 & 0.78 & 0.77 & 0.80 & 0.83 & 0.85 & 0.87 & 0.89 & 0.91 & 0.92 & 0.95 \\
\hline 50 & 0.80 & 0.79 & 0.81 & 0.84 & 0.87 & 0.88 & 0.90 & 0.92 & 0.94 & 0.96 \\
\hline 60 & 0.81 & 0.80 & 0.83 & 0.85 & 0.89 & 0.90 & 0.92 & 0.94 & 0.95 & 0.97 \\
\hline 70 & 0.81 & 0.81 & 0.83 & 0.86 & 0.89 & 0.90 & 0.92 & 0.94 & 0.95 & 0.98 \\
\hline 80 & 0.82 & 0.82 & 0.84 & 0.87 & 0.90 & 0.91 & 0.93 & 0.95 & 0.96 & 0.99 \\
\hline 90 & 0.83 & 0.83 & 0.85 & 0.88 & 0.90 & 0.91 & 0.94 & 0.96 & 0.97 & 1.00 \\
\hline 100 & 0.85 & 0.84 & 0.86 & 0.88 & 0.91 & 0.92 & 0.94 & 0.97 & 0.98 & 1.01 \\
\hline 110 & 0.86 & 0.85 & 0.87 & 0.90 & 0.92 & 0.93 & 0.95 & 0.98 & 0.99 & 1.02 \\
\hline 120 & 0.87 & 0.87 & 0.88 & 0.91 & 0.94 & 0.94 & 0.97 & 0.99 & 1.00 & 1.03 \\
\hline 130 & 0.88 & 0.88 & 0.90 & 0.92 & 0.95 & 0.96 & 0.98 & 1.00 & 1.02 & 1.04 \\
\hline 140 & 0.89 & 0.90 & 0.91 & 0.94 & 0.96 & 0.97 & 0.99 & 1.01 & 1.03 & 1.05 \\
\hline 150 & 0.90 & 0.91 & 0.92 & 0.95 & 0.98 & 0.98 & 1.00 & 1.02 & 1.04 & 1.06 \\
\hline 160 & 0.91 & 0.92 & 0.93 & 0.96 & 0.99 & 0.99 & 1.01 & 1.03 & 1.05 & 1.07 \\
\hline 170 & 0.92 & 0.93 & 0.94 & 0.97 & 1.00 & 1.00 & 1.02 & 1.04 & 1.06 & 1.08 \\
\hline 180 & 0.93 & 0.94 & 0.95 & 0.98 & 1.00 & 1.01 & 1.03 & 1.05 & 1.07 & 1.09 \\
\hline 190 & 0.94 & 0.95 & 0.96 & 0.98 & 1.01 & 1.01 & 1.04 & 1.06 & 1.07 & 1.10 \\
\hline 200 & 0.95 & 0.96 & 0.97 & 0.99 & 1.02 & 1.02 & 1.04 & 1.07 & 1.08 & 1.10 \\
\hline 210 & 0.95 & 0.97 & 0.98 & 1.00 & 1.03 & 1.03 & 1.05 & 1.08 & 1.09 & 1.11 \\
\hline 220 & 0.96 & 0.97 & 0.99 & 1.01 & 1.04 & 1.04 & 1.06 & 1.08 & 1.10 & 1.12 \\
\hline 230 & 0.97 & 0.98 & 0.99 & 1.01 & 1.04 & 1.04 & 1.07 & 1.09 & 1.10 & 1.13 \\
\hline 240 & 0.98 & 0.99 & 1.00 & 1.02 & 1.05 & 1.05 & 1.07 & 1.10 & 1.11 & 1.14 \\
\hline 250 & 0.98 & 1.00 & 1.01 & 1.03 & 1.06 & 1.06 & 1.08 & 1.11 & 1.12 & 1.14 \\
\hline 260 & 0.99 & 1.00 & 1.02 & 1.04 & 1.07 & 1.07 & 1.09 & 1.11 & 1.12 & 1.15 \\
\hline 270 & 0.99 & 1.01 & 1.02 & 1.05 & 1.07 & 1.07 & 1.10 & 1.12 & 1.13 & 1.16 \\
\hline 280 & 1.00 & 1.02 & 1.03 & 1.05 & 1.08 & 1.08 & 1.10 & 1.13 & 1.14 & 1.16 \\
\hline 290 & 1.01 & 1.03 & 1.04 & 1.06 & 1.09 & 1.09 & 1.11 & 1.13 & 1.14 & 1.17 \\
\hline 300 & 1.01 & 1.03 & 1.04 & 1.07 & 1.10 & 1.09 & 1.11 & 1.14 & 1.15 & 1.17 \\
\hline 310 & 1.02 & 1.04 & 1.05 & 1.07 & 1.11 & 1.10 & 1.12 & 1.14 & 1.15 & 1.18 \\
\hline 320 & 1.03 & 1.05 & 1.06 & 1.08 & 1.11 & 1.11 & 1.13 & 1.15 & 1.16 & 1.18 \\
\hline 330 & 1.03 & 1.05 & 1.06 & 1.09 & 1.12 & 1.11 & 1.13 & 1.16 & 1.17 & 1.18 \\
\hline 340 & 1.04 & 1.05 & 1.07 & 1.09 & 1.12 & 1.12 & 1.14 & 1.17 & 1.18 & 1.19 \\
\hline 350 & 1.04 & 1.06 & 1.07 & 1.09 & 1.12 & 1.12 & 1.14 & 1.17 & 1.18 & 1.19 \\
\hline 360 & 1.04 & 1.06 & 1.07 & 1.10 & 1.13 & 1.12 & 1.14 & 1.17 & 1.19 & 1.20 \\
\hline 370 & 1.04 & 1.06 & 1.07 & 1.10 & 1.13 & 1.13 & 1.14 & 1.18 & 1.20 & 1.20 \\
\hline 380 & 1.05 & 1.07 & 1.08 & 1.10 & 1.14 & 1.13 & 1.15 & 1.18 & 1.20 & 1.22 \\
\hline 390 & 1.05 & 1.07 & 1.08 & 1.11 & 1.14 & 1.14 & 1.16 & 1.19 & 1.21 & 1.23 \\
\hline 400 & 1.06 & 1.07 & 1.09 & 1.11 & 1.15 & 1.14 & 1.16 & 1.20 & 1.23 & 1.26 \\
\hline 410 & 1.06 & 1.08 & 1.09 & 1.12 & 1.15 & 1.15 & 1.17 & 1.21 & 1.25 & 1.31 \\
\hline 420 & 1.06 & 1.08 & 1.10 & 1.12 & 1.16 & 1.15 & 1.18 & 1.23 & 1.30 & 1.41 \\
\hline 430 & 1.06 & 1.08 & 1.10 & 1.12 & 1.16 & 1.16 & 1.19 & 1.26 & 1.41 & 1.64 \\
\hline 440 & 1.07 & 1.09 & 1.10 & 1.13 & 1.17 & 1.17 & 1.20 & 1.33 & 1.61 & 1.70 \\
\hline 450 & 1.07 & 1.09 & 1.11 & 1.14 & 1.19 & 1.19 & 1.24 & 1.47 & 1.67 & 1.54 \\
\hline 460 & 1.08 & 1.10 & 1.13 & 1.16 & 1.21 & 1.23 & 1.32 & 1.68 & 1.52 & 1.51 \\
\hline 470 & 1.08 & 1.10 & 1.15 & 1.19 & 1.25 & 1.31 & 1.49 & 1.63 & 1.49 & 1.50 \\
\hline 480 & 1.08 & 1.11 & 1.20 & 1.25 & 1.34 & 1.46 & 1.66 & 1.50 & 1.48 & 1.49 \\
\hline 490 & 1.09 & 1.12 & 1.25 & 1.35 & 1.47 & 1.58 & 1.52 & 1.49 & 1.48 & \\
\hline 500 & 1.09 & 1.14 & 1.23 & 1.37 & 1.52 & 1.44 & 1.45 & 1.48 & & \\
\hline 510 & 1.09 & 1.14 & 1.21 & 1.31 & 1.42 & 1.39 & 1.43 & 1.48 & & \\
\hline 520 & 1.09 & 1.13 & 1.20 & 1.28 & 1.38 & 1.37 & 1.43 & & & \\
\hline
\end{tabular}


Table 2 (continued)

\begin{tabular}{|c|c|c|c|c|c|c|c|c|c|c|}
\hline \multirow{2}{*}{$\begin{array}{l}T \\
\left({ }^{\circ} \mathrm{C}\right)\end{array}$} & \multicolumn{10}{|c|}{ mole $\% \mathrm{Na}_{2} \mathrm{O}$} \\
\hline & 2 & 5 & 10 & 15 & 20 & 25 & 30 & 35 & 40 & 45 \\
\hline 530 & 1.10 & 1.13 & 1.20 & 1.28 & 1.37 & 1.37 & & & & \\
\hline 540 & 1.10 & 1.13 & 1.20 & 1.28 & 1.36 & 1.36 & & & & \\
\hline 550 & 1.10 & 1.14 & 1.20 & 1.28 & 1.36 & 1.36 & & & & \\
\hline 560 & 1.10 & 1.14 & 1.20 & 1.28 & 1.36 & & & & & \\
\hline 570 & 1.10 & 1.14 & & & & & & & & \\
\hline 580 & 1.10 & 1.14 & & & & & & & & \\
\hline 590 & 1.10 & 1.14 & & & & & & & & \\
\hline 600 & 1.10 & 1.14 & & & & & & & & \\
\hline 610 & 1.10 & 1.14 & & & & & & & & \\
\hline 620 & 1.10 & & & & & & & & & \\
\hline 630 & 1.10 & & & & & & & & & \\
\hline 640 & 1.10 & & & & & & & & & \\
\hline 650 & 1.10 & & & & & & & & & \\
\hline 660 & 1.10 & & & & & & & & & \\
\hline 670 & 1.10 & & & & & & & & & \\
\hline 680 & 1.10 & & & & & & & & & \\
\hline$T_{\mathrm{g}}\left(c_{p}\right)$ & 506 & 505 & 492 & 497 & 497 & 490 & 481 & 464 & 447 & 437 \\
\hline$T_{\mathrm{g}}(\mathrm{d} V / \mathrm{d} T)$ & 506 & 502 & 495 & 498 & 495 & 489 & 478 & 463 & 447 & 436 \\
\hline
\end{tabular}

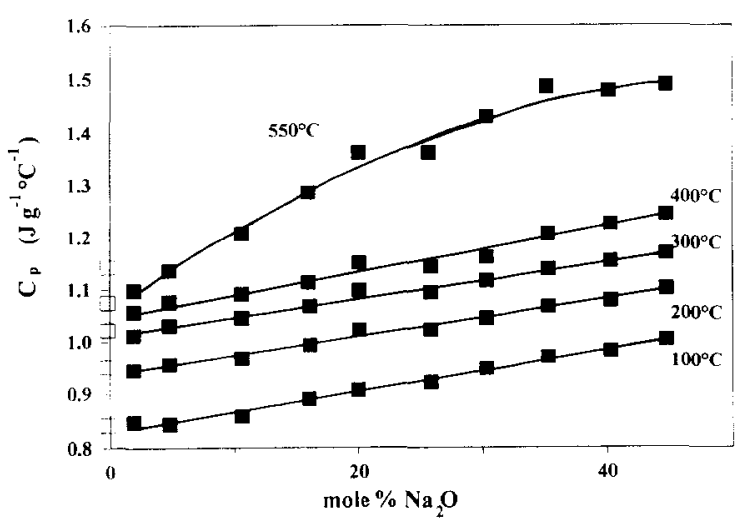

Fig. 2. Isothermal heat capacities of the glasses $\left(100^{\circ}, 200^{\circ}\right.$, $\left.300^{\circ}, 400^{\circ} \mathrm{C}\right)$ and supercooled melts $\left(550^{\circ} \mathrm{C}\right.$ - for the Narich samples the heat capacity was extrapolated up to $550^{\circ} \mathrm{C}$ as the onset of crystallization prevented its measurement up to this temperature). The errors are less than the size of the symbols. The data for $\mathrm{SiO}_{2}$ (Table 3) are also plotted.

The non-linear composition dependence of the heat capacity of the supercooled liquids indicates that multi-linear fits of heat capacity will have only limited success in predicting the thermal properties of such systems.

\subsection{Molar volume and thermal expansivity}

\subsubsection{Molar volume at room temperature}

The glass densities at room temperature ( Table 4 and volumes in Fig. 3 ) increase non-linearly with increasing $\mathrm{Na}_{2} \mathrm{O}$. The density of glasses in this system has been studied extensively (Mazurin et al., 1983). Bansal and Doremus (1986) determined mean values for the densities from 15 different studies. These values are in good agreement with our data though our data are consistently higher, generally by $\sim 0.2 \%$. An explanation can be found in the fact that, in the reported studies, melts were generally quenched by pouring them onto a steel plate. This corresponds to a cooling rate for the glasses of some $10-100^{\circ} \mathrm{C} \min ^{-1}$. In our study we cooled the glasses with $5^{\circ} \mathrm{C} \mathrm{min}^{-1}$ from the liquid state before the determination of density. Therefore, the higher density of the present glasses could result from their lower fictive temperature. (Based on the data presented in Table 7, an order of magnitude increase in quench rate results in $\leqslant 0.15 \%$ decrease in density.) 
Table 3

Literature data for $\mathrm{SiO}_{2}$ glass and melt used in the present calculations

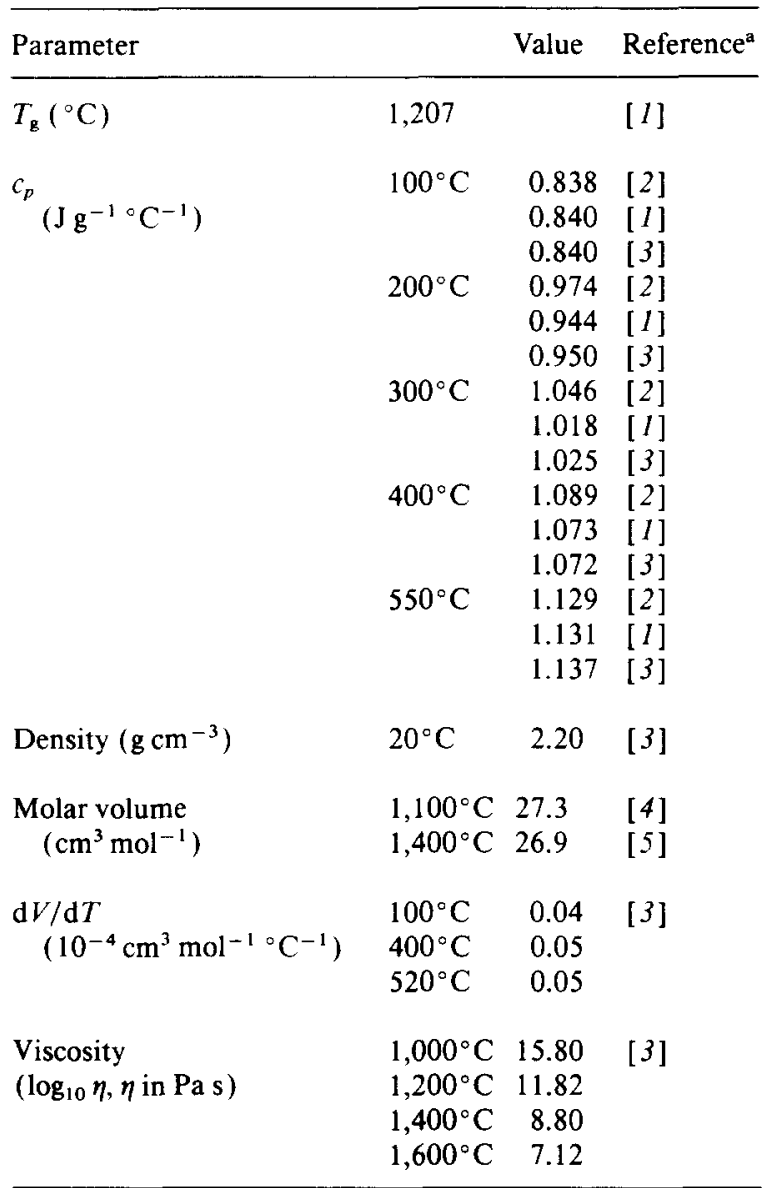

aeferences: [1] = Richet and Bottinga (1984); [2] = Robie et al. (1979); [3]=Bansal and Doremus (1986); [4] = Brückner (1970); [5] = Lange and Carmichael (1990).

Table 4

Density of the glasses at $19.8^{\circ} \mathrm{C}$

\begin{tabular}{llll}
\hline $\begin{array}{l}\mathrm{Na}_{2} \mathrm{O} \\
\text { content } \\
(\mathrm{mole} \%)\end{array}$ & $\begin{array}{l}\rho \\
\left(\mathrm{g} \mathrm{cm}^{-3)}\right.\end{array}$ & $\begin{array}{l}\mathrm{Na}_{2} \mathrm{O} \\
\text { content } \\
(\mathrm{mole} \%)\end{array}$ & $\begin{array}{l}\rho \\
\left(\mathrm{g} \mathrm{cm}^{-3}\right)\end{array}$ \\
\hline 2 & 2.220 & 25 & 2.439 \\
5 & 2.247 & 30 & 2.473 \\
10 & 2.295 & 35 & 2.507 \\
15 & 2.354 & 40 & 2.534 \\
20 & 2.398 & 45 & 2.554 \\
\hline
\end{tabular}

Densities $\pm 0.2 \%$ at $1 \sigma$.

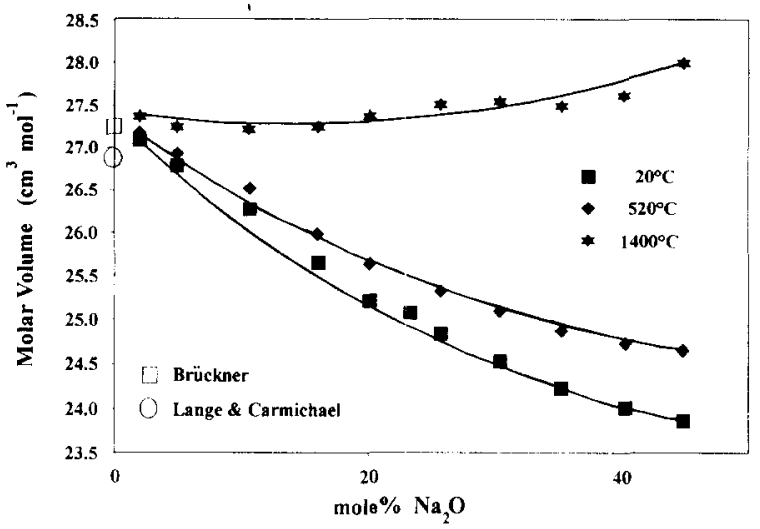

Fig. 3. Molar volumes of the glasses $\left(20^{\circ} \mathrm{C}\right)$, supercooled melts $\left(520^{\circ} \mathrm{C}\right)$ and stable melts $\left(1400^{\circ} \mathrm{C}\right)$. The errors are the size of the symbols. The data for $\mathrm{SiO}_{2}$ are also plotted.

\subsubsection{Thermal expansion of the glasses and su- percooled liquids}

The thermal expansion of the glasses measured in the dilatometer is linearly dependent on temperature. The molar volume of the glasses up to the glass transition (Table 5) can be described as a second-order polynomial using the room temperature density and the glassy expansivity data (Table 6). Our data for the expansion of the glasses are comparable to the literature data [for a summary, see Mazurin et al. (1983)]. Systematic studies of thermal expansion over a wide range of compositions are reported by Samsoen (1926, 1928), Turner and Winks (1930), and Shelby (1976). Their data are in excellent agreement with ours.

In the supercooled liquid the thermal expansion and the molar volume were determined from the combination of calorimetry and dilatometry (Table 7). The thermal expansivity increases non-linearly with increasing $\mathrm{Na}_{2} \mathrm{O}$ (Fig. 4; to enable an isothermal comparison the expansivities of the samples rich in $\mathrm{Na}$ are extrapolated in temperature). The continuous increase is interrupted by the data point at 10 mole $\% \mathrm{Na}_{2} \mathrm{O}$. This deviation lies outside of the error of the measurements. A satisfactory explanation for this cannot be given though it is worth noting that the same sample also shows a deviation in the glass transition temperature.

Some authors also give values for the thermal 
Table 5

Molar volume $\left(\mathrm{cm}^{3} \mathrm{~mol}^{-1}\right)$ for the glasses and supercooled melts (cooling rate: $1{ }^{\circ} \mathrm{C} \mathrm{min}-1 /$ heating rate: $5^{\circ} \mathrm{C} \mathrm{min}-1$ )

\begin{tabular}{|c|c|c|c|c|c|c|c|c|c|c|}
\hline \multirow{2}{*}{$\begin{array}{l}T \\
\left({ }^{\circ} \mathrm{C}\right)\end{array}$} & \multicolumn{10}{|c|}{ mole $\% \mathrm{Na}_{2} \mathrm{O}$} \\
\hline & 2 & 5 & 10 & 15 & 20 & 25 & 30 & 35 & 40 & 45 \\
\hline 30 & 27.08 & 26.78 & 26.26 & 25.65 & 25.22 & 24.84 & 24.53 & 24.24 & 24.02 & 23.87 \\
\hline 40 & 27.09 & 26.78 & 26.26 & 25.66 & 25.23 & 24.84 & 24.54 & 24.25 & 24.02 & 23.88 \\
\hline 50 & 27.09 & 26.79 & 26.27 & 25.66 & 25.24 & 24.85 & 24.55 & 24.25 & 24.03 & 23.89 \\
\hline 60 & 27.09 & 26.79 & 26.27 & 25.67 & 25.24 & 24.86 & 24.56 & 24.26 & 24.04 & 23.90 \\
\hline 70 & 27.09 & 26.79 & 26.28 & 25.67 & 25.25 & 24.87 & 24.57 & 24.28 & 24.05 & 23.91 \\
\hline 80 & 27.09 & 26.79 & 26.28 & 25.68 & 25.26 & 24.89 & 24.58 & 24.29 & 24.06 & 23.93 \\
\hline 90 & 27.09 & 26.80 & 26.29 & 25.69 & 25.27 & 24.89 & 24.59 & 24.30 & 24.08 & 29.94 \\
\hline 100 & 27.10 & 26.80 & 26.29 & 25.69 & 25.28 & 24.90 & 24.60 & 24.31 & 24.09 & 23.95 \\
\hline 110 & 27.10 & 26.80 & 26.30 & 25.70 & 25.29 & 24.91 & 24.61 & 24.32 & 24.10 & 23.96 \\
\hline 120 & 27.10 & 26.80 & 26.30 & 25.71 & 25.29 & 24.92 & 24.62 & 24.33 & 24.11 & 23.98 \\
\hline 130 & 27.10 & 26.81 & 26.31 & 25.72 & 25.30 & 24.93 & 24.63 & 24.34 & 24.13 & 23.99 \\
\hline 140 & 27.10 & 26.81 & 26.31 & 25.72 & 25.31 & 24.94 & 24.64 & 24.35 & 24.14 & 24.00 \\
\hline 150 & 27.11 & 26.81 & 26.32 & 25.73 & 25.32 & 24.95 & 24.65 & 24.36 & 24.15 & 24.02 \\
\hline 160 & 27.11 & 26.82 & 26.32 & 25.73 & 25.32 & 24.96 & 24.66 & 24.38 & 24.17 & 24.03 \\
\hline 170 & 27.11 & 26.82 & 26.33 & 25.74 & 25.33 & 24.97 & 24.67 & 24.39 & 24.18 & 24.04 \\
\hline 180 & 27.11 & 26.82 & 26.33 & 25.75 & 25.34 & 24.98 & 24.68 & 24.40 & 24.19 & 24.06 \\
\hline 190 & 27.11 & 26.83 & 26.34 & 25.76 & 25.35 & 24.99 & 24.69 & 24.41 & 24.21 & 24.07 \\
\hline 200 & 27.12 & 26.83 & 26.34 & 25.76 & 25.36 & 25.00 & 24.70 & 24.43 & 24.22 & 24.09 \\
\hline 210 & 27.12 & 26.83 & 26.35 & 25.77 & 25.37 & 25.01 & 24.71 & 24.44 & 24.23 & 24.10 \\
\hline 220 & 27.12 & 26.84 & 26.35 & 25.78 & 25.38 & 25.02 & 24.73 & 24.45 & 24.25 & 24.12 \\
\hline 230 & 27.12 & 26.84 & 26.36 & 25.78 & 25.39 & 25.03 & 24.74 & 24.46 & 24.26 & 24.13 \\
\hline 240 & 27.12 & 26.84 & 26.37 & 25.79 & 25.40 & 25.04 & 24.75 & 24.48 & 24.28 & 24.15 \\
\hline 250 & 27.13 & 26.85 & 26.37 & 25.80 & 25.41 & 25.05 & 24.76 & 24.49 & 24.29 & 24.16 \\
\hline 260 & 27.13 & 26.85 & 26.38 & 25.81 & 25.41 & 25.06 & 24.77 & 24.50 & 24.31 & 24.18 \\
\hline 270 & 27.13 & 26.85 & 26.38 & 25.81 & 25.42 & 25.07 & 24.78 & 24.51 & 24.32 & 24.19 \\
\hline 280 & 27.14 & 26.86 & 26.39 & 25.82 & 25.43 & 25.08 & 24.79 & 24.53 & 24.34 & 24.21 \\
\hline 290 & 27.14 & 26.86 & 26.39 & 25.83 & 25.44 & 25.09 & 24.81 & 24.54 & 24.35 & 24.23 \\
\hline 300 & 27.14 & 26.86 & 26.40 & 25.84 & 25.45 & 25.10 & 24.82 & 24.56 & 24.37 & 24.24 \\
\hline 310 & 27.14 & 26.87 & 26.40 & 25.85 & 25.46 & 25.11 & 24.83 & 24.57 & 24.38 & 24.26 \\
\hline 320 & 27.14 & 26.87 & 26.41 & 25.85 & 25.47 & 25.12 & 24.84 & 24.58 & 24.40 & 24.27 \\
\hline 330 & 27.15 & 26.87 & 26.41 & 25.86 & 25.48 & 25.13 & 24.86 & 24.60 & 24.41 & 24.29 \\
\hline 340 & 27.15 & 26.88 & 26.42 & 25.87 & 25.49 & 25.14 & 24.87 & 24.61 & 24.43 & 24.31 \\
\hline 350 & 27.15 & 26.88 & 26.42 & 25.88 & 25.50 & 25.15 & 24.88 & 24.63 & 24.44 & 24.33 \\
\hline 360 & 27.15 & 26.88 & 26.43 & 25.89 & 25.51 & 25.16 & 24.89 & 24.64 & 24.46 & 24.34 \\
\hline 370 & 27.15 & 26.89 & 26.43 & 25.90 & 25.52 & 25.17 & 24.90 & 24.65 & 24.48 & 24.36 \\
\hline 380 & 27.15 & 26.89 & 26.44 & 25.90 & 25.53 & 25.18 & 24.92 & 24.67 & 24.49 & 24.38 \\
\hline 390 & 27.16 & 26.89 & 26.45 & 25.91 & 25.54 & 25.19 & 24.93 & 24.68 & 24.51 & 24.39 \\
\hline 400 & 27.16 & 26.90 & 26.45 & 25.92 & 25.55 & 25.20 & 24.94 & 24.70 & 24.53 & 24.41 \\
\hline 410 & 27.16 & 26.90 & 26.46 & 25.93 & 25.56 & 25.22 & 24.96 & 24.72 & 24.55 & 24.43 \\
\hline 420 & 27.17 & 26.90 & 26.46 & 25.94 & 25.57 & 25.23 & 24.97 & 24.73 & 24.57 & 24.46 \\
\hline 430 & 27.17 & 26.91 & 26.47 & 25.95 & 25.58 & 25.24 & 24.98 & 24.75 & 24.59 & 24.49 \\
\hline 440 & 27.17 & 26.91 & 26.47 & 25.96 & 25.59 & 25.25 & 25.00 & 24.77 & 24.62 & 24.53 \\
\hline 450 & 27.17 & 26.91 & 26.48 & 25.96 & 25.60 & 25.26 & 25.02 & 24.79 & 24.66 & 24.58 \\
\hline 460 & 27.18 & 26.92 & 26.49 & 25.97 & 25.61 & 25.28 & 25.04 & 24.82 & 24.70 & \\
\hline 470 & 27.18 & 26.92 & 26.49 & 25.99 & 25.62 & 25.30 & 25.06 & 24.86 & & \\
\hline 480 & 27.18 & 26.93 & 26.50 & 26.00 & 25.64 & 25.32 & 25.10 & 24.89 & & \\
\hline 490 & 27.19 & 26.93 & 26.51 & 26.02 & 25.66 & 25.36 & 25.14 & & & \\
\hline 500 & 27.19 & 26.94 & 26.53 & 26.04 & 25.70 & 25.39 & & & & \\
\hline 510 & 27.19 & 26.94 & 26.54 & 26.06 & 25.72 & 25.42 & & & & \\
\hline 520 & 27.19 & 26.95 & 26.55 & 26.08 & 25.74 & & & & & \\
\hline 530 & 27.20 & 26.95 & 26.56 & 26.10 & & & & & & \\
\hline
\end{tabular}


Table 5 (continued)

\begin{tabular}{|c|c|c|c|c|c|c|c|c|c|c|}
\hline \multirow{2}{*}{$\begin{array}{l}T \\
\left({ }^{\circ} \mathrm{C}\right)\end{array}$} & \multicolumn{10}{|c|}{ mole $\% \mathrm{Na}_{2} \mathrm{O}$} \\
\hline & 2 & 5 & 10 & 15 & 20 & 25 & 30 & 35 & 40 & 45 \\
\hline 540 & 27.20 & 26.96 & 26.57 & & & & & & & \\
\hline 550 & 27.20 & 26.96 & 26.58 & & & & & & & \\
\hline 560 & 27.21 & 26.97 & & & & & & & & \\
\hline 570 & 27.21 & 26.97 & & & & & & & & \\
\hline 580 & 27.22 & 26.98 & & & & & & & & \\
\hline 590 & 27.22 & 26.98 & & & & & & & & \\
\hline 600 & 27.22 & & & & & & & & & \\
\hline 610 & 27.23 & & & & & & & & & \\
\hline 620 & 27.23 & & & & & & & & & \\
\hline 630 & 27.23 & & & & & & & & & \\
\hline 640 & 27.23 & & & & & & & & & \\
\hline 650 & 27.23 & & & & & & & & & \\
\hline 660 & 27.24 & & & & & & & & & \\
\hline 670 & 27.24 & & & & & & & & & \\
\hline 680 & 27.24 & & & & & & & & & \\
\hline
\end{tabular}

Table 6

Molar volume $\left(\mathrm{cm}^{3} \mathrm{~mol}^{-1}\right)$ of the glasses as a function of temperature:

$V\left(\mathrm{~cm}^{3} \mathrm{~mol}^{-1}\right)=a+b \cdot 10^{-4} T+c \cdot 10^{-7} T^{2}, \quad$ with $T=$ temperature $\left({ }^{\circ} \mathrm{C}\right)$

\begin{tabular}{llllll}
\hline & $a$ & $b$ & $c$ & $\begin{array}{l}T \\
\left({ }^{\circ} \mathrm{C}\right)\end{array}$ & $\begin{array}{c}\text { Molar weight } \\
\left(\mathrm{g} \mathrm{mol}^{-1}\right)\end{array}$ \\
\hline $2 \mathrm{~mole} \% \mathrm{Na}_{2} \mathrm{O}$ & 27.08 & 1.43 & 1.20 & $20-440$ & 60.121 \\
$5 \mathrm{~mole} \% \mathrm{Na}_{2} \mathrm{O}$ & 26.77 & 2.76 & 1.33 & $20-420$ & 60.176 \\
$10 \mathrm{~mole} \% \mathrm{Na}_{2} \mathrm{O}$ & 26.26 & 4.67 & 1.19 & $20-420$ & 60.285 \\
$15 \mathrm{~mole} \% \mathrm{Na}_{2} \mathrm{O}$ & 25.64 & 6.03 & 2.71 & $20-420$ & 60.386 \\
$20 \mathrm{~mole} \% \mathrm{Na}_{2} \mathrm{O}$ & 25.20 & 7.40 & 3.85 & $20-420$ & 60.464 \\
$25 \mathrm{~mole} \% \mathrm{Na}_{2} \mathrm{O}$ & 24.82 & 8.48 & 3.51 & $20-410$ & 60.570 \\
$30 \mathrm{~mole} \% \mathrm{Na}_{2} \mathrm{O}$ & 24.51 & 9.18 & 5.27 & $20-400$ & 60.660 \\
$35 \mathrm{~mole} \% \mathrm{Na}_{2} \mathrm{O}$ & 24.21 & 10.17 & 5.63 & $20-390$ & 60.751 \\
$40 \mathrm{~mole} \% \mathrm{Na}_{2} \mathrm{O}$ & 23.99 & 10.46 & 7.39 & $20-370$ & 60.845 \\
$45 \mathrm{~mole} \% \mathrm{Na}_{2} \mathrm{O}$ & 23.84 & 10.80 & 8.80 & $20-360$ & 60.934 \\
\hline
\end{tabular}

Cooling-rate/heating-rate: $5^{\circ} \mathrm{C} \mathrm{min}^{-1} / 5^{\circ} \mathrm{C} \mathrm{min}^{-1}$.

expansivity of the supercooled liquids above the glass transition. Those data have been obtained by determining the slope of the $\mathrm{d} L$ curve in the inflection point above the beginning of the glass transition interval (the equivalent of using "peak" values, the thermal expansivity at the maximum of the $\mathrm{d} V / \mathrm{d} T$ curve; see also Knoche et al., 1992a). This explains the overestimates of the expansivity in the data from Samsoen (1926, 1928), Amrhein (1963), and Suzuki and Abe (1981). In contrast to this, Turner and Winks (1930) and Maklad and Kreidl (1971) report a thermal expansivity above $T_{\mathrm{g}}$ which is clearly much too low. This is most likely due to too large a force being exerted on the sample during the measurement, resulting in appreciable viscous deformation under the applied load in the glass transition interval.

The thermal expansivities of the supercooled liquids illustrated in Fig. 4 can be used to extrapolate from $98 \%$ to $100 \% \mathrm{SiO}_{2}$. The resulting expansivity of $\mathrm{SiO}_{2}$ liquid is extremely small, within error of zero. This estimate of the relaxed, lowtemperature expansivity of $\mathrm{SiO}_{2}$ compares with 
Table 7

Calculated $\mathrm{d} V / \mathrm{d} T$ and $\alpha_{V}[=(1 / V) \cdot(\mathrm{d} V / \mathrm{d} T)]$ from the comparison of the calorimetry and dilatometry data, together with the molar volume of the supercooled melts at temperature $T$

\begin{tabular}{|c|c|c|c|c|}
\hline & $\begin{array}{l}\mathrm{d} V / \mathrm{d} T \\
\left(10^{-4} \mathrm{~cm}^{3} \mathrm{~mol}^{-1}{ }^{\circ} \mathrm{C}^{-1}\right)\end{array}$ & $\begin{array}{l}\alpha_{V} \\
\left(10^{-6}{ }^{\circ} \mathrm{C}^{-1}\right)\end{array}$ & $\begin{array}{l}V^{\prime} \\
\left(\mathrm{cm}^{3} \mathrm{~mol}^{-1}\right)\end{array}$ & $\begin{array}{l}T \\
\left({ }^{\circ} \mathrm{C}\right)\end{array}$ \\
\hline 2 mole $\% \mathrm{Na}_{2} \mathrm{O}$ & $4.0 \pm 1.0$ & $14.6 \pm 2.9$ & $27.179 \pm 0.010$ & 560 \\
\hline 5 mole $\% \mathrm{Na}_{2} \mathrm{O}$ & $5.0 \pm 0.5$ & $18.6 \pm 1.9$ & $26.948 \pm 0.003$ & 560 \\
\hline 10 mole $\% \mathrm{Na}_{2} \mathrm{O}$ & $10.1 \pm 0.4$ & $38.0 \pm 1.5$ & $26.531 \pm 0.004$ & 540 \\
\hline 15 mole $\% \mathrm{Na}_{2} \mathrm{O}$ & $18.1 \pm 0.7$ & $69.6 \pm 2.7$ & $26.026 \pm 0.003$ & 540 \\
\hline 20 mole $\% \mathrm{Na}_{2} \mathrm{O}$ & $22.5 \pm 1.0$ & $87.6 \pm 4.0$ & $25.686 \pm 0.004$ & 540 \\
\hline 25 mole $\% \mathrm{Na}_{2} \mathrm{O}$ & $24.6 \pm 0.7$ & $97.1 \pm 2.7$ & $25.346 \pm 0.001$ & 530 \\
\hline 30 mole $\% \mathrm{Na}_{2} \mathrm{O}$ & $26.9 \pm 0.9$ & $107.3 \pm 3.8$ & $25.092 \pm 0.004$ & 520 \\
\hline $35 \mathrm{~mole} \% \mathrm{Na}_{2} \mathrm{O}$ & $30.1 \pm 0.6$ & $121.0 \pm 2.4$ & $24.840 \pm 0.003$ & 510 \\
\hline 40 mole $\% \mathrm{Na}_{2} \mathrm{O}$ & $31.0 \pm 0.7$ & $125.7 \pm 3.0$ & $24.639 \pm 0.002$ & 490 \\
\hline 45 mole $\% \mathrm{Na}_{2} \mathrm{O}$ & $34.2 \pm 1.6$ & $139.5 \pm 6.7$ & $24.512 \pm 0.010$ & 480 \\
\hline
\end{tabular}

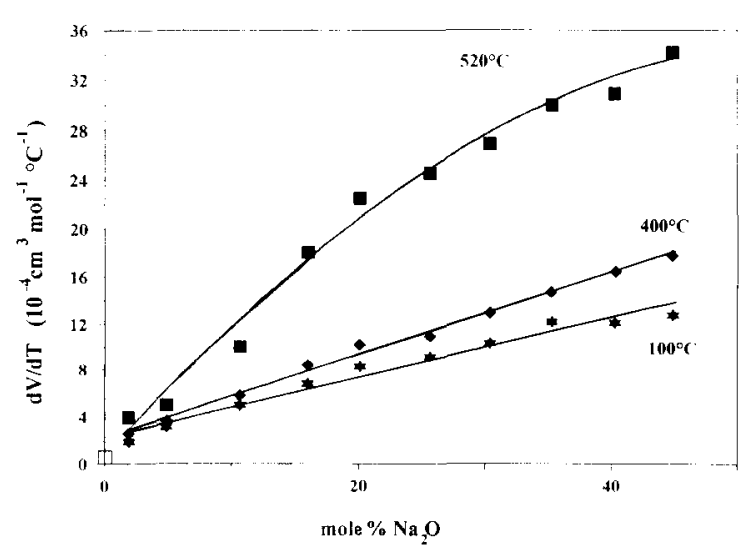

Fig. 4. Isothermal molar expansivities of the glasses $\left(100^{\circ}\right.$, $\left.400^{\circ} \mathrm{C}\right)$ and melts $\left(520^{\circ} \mathrm{C}\right)$. The errors are less than the size of the symbols. The data for $\mathrm{SiO}_{2}$ (see Table 3) are also plotted.

the low expansivity measured for $\mathrm{SiO}_{2}$ glass in this temperature range (Brückner, 1970). These results, taken together, imply that the glass transition in $\mathrm{SiO}_{2}$ will impart a very small expansivity change to the melt. The generally small expansivity of $\mathrm{SiO}_{2}$ indicated in Fig. 4 is similar to the result of multi-component fits of silicate melt densities as well (Bottinga and Weill, 1970; Lange and Carmichael, 1990). It is worth pointing out, however, that the non-linear composition dependence of the thermal expansivity in this system implies a higher effective expansivity of the $\mathrm{SiO}_{2}$ component in the silicate melt structure. This excess behavior of the expansivity is observed for the first time in this study. One might interpret the non-linear composition dependence of expansivity in terms of a fundamental difference in the expansivity of $\mathrm{SiO}_{4}$ tetrahedra that are fully polymerized vs. those which have non-bridging oxygens. The proposal by Bockris et al. (1956) that the expansivity of $\mathrm{SiO}_{2}-$ rich silicate melts on this (and other) joins goes through zero and becomes negative with increasing $\mathrm{SiO}_{2}$ content appears is refuted by the present data.

\subsection{Viscosity}

The data for the viscosity of the melts are listed in Table 8. Not all of the ten samples could be studied with the micropenetration and/or the concentric cylinder technique. The surface of the samples with 2, 5 and 10 mole $\% \mathrm{Na}_{2} \mathrm{O}$ began to crystallize during the micropenetration experiments. For the samples with 2 and 5 mole $\% \mathrm{Na}_{2} \mathrm{O}$ the viscosity at the maximum experimental temperatures was still too high to allow equilibrium measurements. Therefore, only for compositions with 15-45 mole $\% \mathrm{Na}_{2} \mathrm{O}$ could low- and hightemperature viscosities be determined.

Non-Arrhenian behavior was observed for all compositions studied. The low-temperature viscosity data, together with the high-temperature viscosity data, were fit within error to a secondorder polynomial (Table 9; Fig. 5). Arrhenian behavior is reported in the literature for the vis- 
Table 8

Viscosity of the melts

\begin{tabular}{|c|c|c|c|c|c|c|c|c|}
\hline & $\begin{array}{l}T \\
\left({ }^{\circ} \mathrm{C}\right)\end{array}$ & $\begin{array}{l}\log _{10} \eta \\
(\eta \text { in } \mathrm{Pa} s)\end{array}$ & & $\begin{array}{l}T \\
\left({ }^{\circ} \mathrm{C}\right)\end{array}$ & $\begin{array}{l}\log _{10} \eta \\
(\eta \text { in } \mathrm{Pas})\end{array}$ & & $\begin{array}{l}T \\
\left({ }^{\circ} \mathrm{C}\right)\end{array}$ & $\begin{array}{l}\log _{10} \eta \\
(\eta \text { in Pas })\end{array}$ \\
\hline \multirow[t]{6}{*}{5 mole $\% \mathrm{Na}_{2} \mathrm{O}$} & 1,575 & 2.24 & \multirow[t]{13}{*}{25 mole $\% \mathrm{Na}_{2} \mathrm{O}$} & 494.4 & 10.73 & \multirow[t]{13}{*}{40 mole $\% \mathrm{Na}_{2} \mathrm{O}$} & 444.5 & 10.83 \\
\hline & 1,600 & 2.18 & & 502.6 & 10.29 & & 454.2 & 10.40 \\
\hline & 1,625 & 2.09 & & 509.2 & 9.98 & & 464.0 & 9.94 \\
\hline & 1,650 & 2.01 & & 519.0 & 9.69 & & 474.5 & 9.52 \\
\hline & 1,675 & 1.94 & & 533.7 & 9.28 & & 484.1 & 9.20 \\
\hline & & & & 543.5 & 8.94 & & 1,000 & 1.57 \\
\hline \multirow[t]{5}{*}{10 mole $\% \mathrm{Na}_{2} \mathrm{O}$} & 1,500 & 1.77 & & 1,200 & 1.53 & & 1,050 & 1.37 \\
\hline & 1,550 & 1.60 & & 1,250 & 1.37 & & 1,100 & 1.11 \\
\hline & 1,600 & 1.43 & & 1,300 & 1.21 & & 1,150 & 0.93 \\
\hline & 1,650 & 1.28 & & 1,350 & 1.05 & & 1,200 & 0.72 \\
\hline & & & & 1,400 & 0.91 & & 1,250 & 0.57 \\
\hline \multirow{9}{*}{15 mole $\% \mathrm{Na}_{2} \mathrm{O}$} & 523.9 & 11.05 & & 1,450 & 0.79 & & 1.300 & 0.38 \\
\hline & 542.9 & 10.57 & & & & & & \\
\hline & 582.5 & 9.53 & \multirow[t]{12}{*}{30 mole $\% \mathrm{Na}_{2} \mathrm{O}$} & 474.1 & 11.08 & \multirow[t]{24}{*}{45 mole $\% \mathrm{Na}_{2} \mathrm{O}$} & 433.2 & 10.76 \\
\hline & 1,350 & 1.77 & & 489.0 & 10.42 & & 444.1 & 10.22 \\
\hline & 1,400 & 1.59 & & 504.4 & 9.86 & & 454.0 & 9.73 \\
\hline & 1,450 & 1.42 & & 514.4 & 9.35 & & 463.6 & 9.30 \\
\hline & 1,500 & 1.28 & & 1,050 & 1.99 & & 1,100 & 0.65 \\
\hline & 1,600 & 1.00 & & 1,100 & 1.76 & & 1,125 & 0.56 \\
\hline & & & & 1,150 & 1.52 & & 1,150 & 0.40 \\
\hline \multirow[t]{17}{*}{20 mole $\% \mathrm{Na}_{2} \mathrm{O}$} & 504.3 & 10.63 & & 1,200 & 1.32 & & 1,175 & 0.34 \\
\hline & 518.9 & 10.41 & & 1,250 & 1.14 & & 1,200 & 0.25 \\
\hline & 533.4 & 9.90 & & 1,300 & 0.98 & & 1,225 & 0.16 \\
\hline & 548.5 & 9.38 & & 1,350 & 0.83 & & 1,250 & 0.08 \\
\hline & 1,250 & 1.70 & & & & & & \\
\hline & 1,300 & 1.49 & \multirow[t]{12}{*}{35 mole $\% \mathrm{Na}_{2} \mathrm{O}$} & 464.0 & 10.78 & & & \\
\hline & 1,350 & 1.32 & & 474.4 & 10.27 & & & \\
\hline & 1,400 & 1.17 & & 484.0 & 9.85 & & & \\
\hline & 1,450 & 1.03 & & 493.9 & 9.51 & & & \\
\hline & 1,500 & 0.90 & & 503.9 & 9.16 & & & \\
\hline & & & & 1,050 & 1.72 & & & \\
\hline & & & & 1,100 & 1.47 & & & \\
\hline & & & & 1,150 & 1.32 & & & \\
\hline & & & & 1,200 & 1.05 & & & \\
\hline & & & & 1,250 & 0.93 & & & \\
\hline & & & & 1,300 & 0.73 & & & \\
\hline & & & & 1,350 & 0.58 & & & \\
\hline
\end{tabular}

Viscosity $\pm 15 \%\left( \pm 0.10 \log _{10}\right)$ from $10^{9}$ to $10^{11} \mathrm{~Pa}$ s. Viscosity $\pm 5 \%\left( \pm 0.05 \log _{10}\right)$ from $10^{0}$ to $10^{5} \mathrm{~Pa}$.

cosity of $\mathrm{SiO}_{2}$ melt (e.g., Richet, 1984). In Fig. 5 it can be seen that the curvature of the nonArrhenian curves decreases with increasing $\mathrm{SiO}_{2}$ content.

In an isothermal plot of the viscosities as a function of composition (Fig. 6) an inflection point can be seen at all temperatures. As this inflection point occurs consistently at all temperatures, i.e. is obtained from high-temperature measurements as well as from low-temperature measurements, we can exclude the possibility that it is an experimental artifact. The inflection point generally occurs at a composition around 30 mole $\% \mathrm{Na}_{2} \mathrm{O}$ with exception of the $500^{\circ} \mathrm{C}$ isotherm where the inflection point lies at $\sim 25$ mole $\% \mathrm{Na}_{2} \mathrm{O}$. The numerical description of the isothermal viscosities with a polynomial of third order (i.e. with an inflection point) can be jus- 
Table 9

Viscosity as a function of temperature:

$\log _{10} \eta(\eta$ in Pa s $)=a+b x+c x^{2}, \quad$ with $x=10^{4} / T$ and $T$ in $\mathrm{K}$

\begin{tabular}{rrrc}
\hline & $a$ & $b$ & $c$ \\
\hline 2 mole $\% \mathrm{Na}_{2} \mathrm{O}$ & - & - & - \\
5 mole $\% \mathrm{Na}_{2} \mathrm{O}$ & -3.646 & 1.089 & - \\
10 mole $\% \mathrm{Na}_{2} \mathrm{O}$ & -4.506 & 1.112 & - \\
15 mole $\% \mathrm{Na}_{2} \mathrm{O}$ & -2.027 & 0.209 & 0.067 \\
20 mole $\% \mathrm{Na}_{2} \mathrm{O}$ & -1.152 & -0.077 & 0.078 \\
25 mole $\% \mathrm{Na}_{2} \mathrm{O}$ & 0.794 & -0.595 & 0.103 \\
30 mole $\% \mathrm{Na}_{2} \mathrm{O}$ & 1.173 & -0.712 & 0.108 \\
35 mole $\% \mathrm{Na}_{2} \mathrm{O}$ & 0.562 & -0.596 & 0.099 \\
40 mole $\% \mathrm{Na}_{2} \mathrm{O}$ & 0.565 & -0.648 & 0.099 \\
45 mole $\% \mathrm{Na}_{2} \mathrm{O}$ & 1.207 & -0.883 & 0.110
\end{tabular}

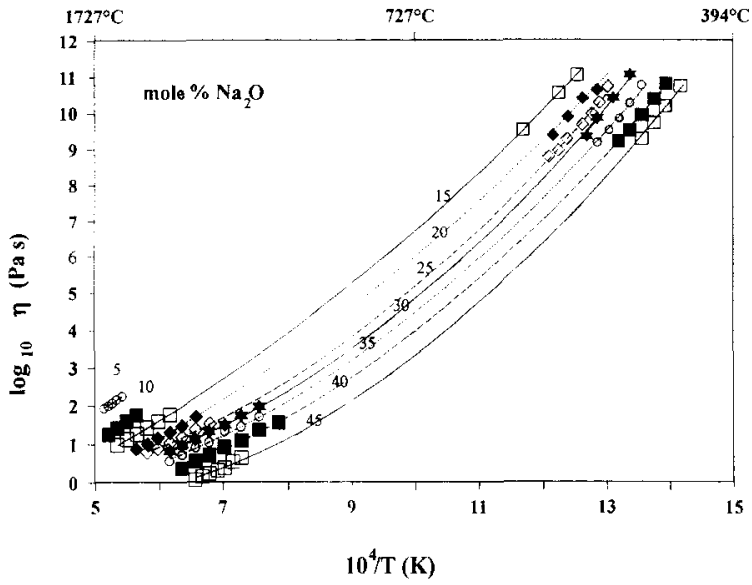

Fig. 5. Plot of melt viscosities in the $\mathrm{Na}_{2} \mathrm{O}-\mathrm{SiO}_{2}$ system. The low-temperature data from micropenetration measurements $\left(10^{9}-10^{11} \mathrm{~Pa} \mathrm{~s}\right)$ can be combined with the high-temperature, concentric cylinder data $\left(10^{0}-10^{3} \mathrm{~Pa} \mathrm{~s}\right)$ through a secondorder polynomial within the error of the methods. This implies a non-Arrhenian behavior for all the samples studied. Errors are less than the size of the symbols. (Complete data sets could not be obtained for all compositions. See explanation in the text.)

tified from the number and quality of data available. For an exact location of the inflection point more data points are required. An influence of the immiscibility gap in the system can be ruled out as this gap occurs at compositions much poorer in $\mathrm{Na}_{2} \mathrm{O}$ (Haller et al., 1974).

The viscosities of melts in the $\mathrm{Na}_{2} \mathrm{O}-\mathrm{SiO}_{2}$ system have been studied extensively [see summary in Mazurin et al. (1983) and Bansal and

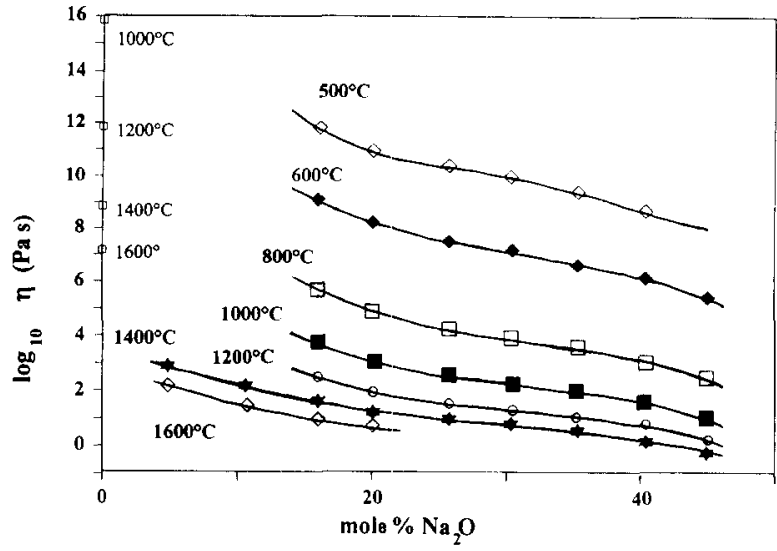

Fig. 6. Isothermal viscosities of the melts from both micropenetration and concentric cylinder determinations. The data for $\mathrm{SiO}_{2}$ (see Table 3) are also plotted. The errors are everywhere less than the size of the symbols.

Doremus (1986)]. The low, superliquidus viscosities have been determined by many authors in relatively good agreement. In contrast, lowtemperature viscosities are less well known and the results of different investigations differ by up to an order of magnitude.

This is also the case in the present study where our high-temperature superliquidus viscosities are in very good agreement with the data from the literature but our low-temperature data are not. This is partly due to the fact that all lowtemperature methods for the determination of viscosity have in the past contained a larger error than those for high temperatures. Slight differences in composition (in $\mathrm{Na}$ content and in minor-element content) also affect the low-temperature viscosities more than the high-temperature viscosities. A subtle inflection in the composition dependence of viscosity exists at all temperatures of comparison. This inflection leads to a deviation of viscosity at higher $\mathrm{Na}_{2} \mathrm{O}$ contents up to more than a $\log _{10}$ unit less that would be predicted from the $\mathrm{SiO}_{2}$-rich melt trend. The observed inflection persists from $500^{\circ}$ to $1600^{\circ} \mathrm{C}$ in the range of $20-30$ mole $\% \mathrm{Na}_{2} \mathrm{O}$. It is clear evidence that viscosities on the $\mathrm{Na}_{2} \mathrm{O}-\mathrm{SiO}_{2}$ join must be explained by a structural model more complex than a simple mixing of bridging and non-bridging oxygens and may presumably in- 
dicate the direct influence of the distribution of $Q$ species on the nature of viscous flow.

\subsection{Glass transition temperatures}

The glass transition temperatures $T_{\mathrm{g}}$ determined from the calorimeter and dilatometer curves are listed in Table 2 (Fig. 7). An overview over the existing literature data for $T_{\mathrm{g}}$ in the system $\mathrm{Na}_{2} \mathrm{O}-\mathrm{SiO}_{2}$ can be found in Mazurin et al. (1983). The $T_{\mathrm{g}}$ data given by different authors differ greatly. Part of the explanation lies in the different thermal histories of the samples, part in the differing experimental techniques (not properties!) used for $T_{\mathrm{g}}$ determination and part in differing definitions for $T_{\mathrm{g}}$. Thus, a comparison of the data is not possible. Some authors have, however, determined the compositional dependence of the glass transition temperature over a wide range of compositions (including low $\mathrm{Na}_{2} \mathrm{O}$ contents) systematically (e.g., Samsoen, 1926, 1928; Turner and Winks, 1930; Shelby, 1976). Especially at low $\mathrm{Na}_{2} \mathrm{O}$ contents, the compositional dependence of $T_{\mathrm{g}}$ is not clear from the literature. Some authors report a continuous increase of $T_{\mathrm{g}}$ with increasing $\mathrm{SiO}_{2}$ content (Maklad and Kreidl, 1971), others report local minima at differing $\mathrm{Na}$ contents (Turner and Winks, 1930 , at 10 mole\% $\mathrm{Na}_{2} \mathrm{O}$; Samsoen, 1926 , 1928 , at $\sim 25$ mole $\% \mathrm{Na}_{2} \mathrm{O}$ ) others observe a decrease of $T_{\mathrm{g}}$ with decreasing $\mathrm{Na}_{2} \mathrm{O}$ content after

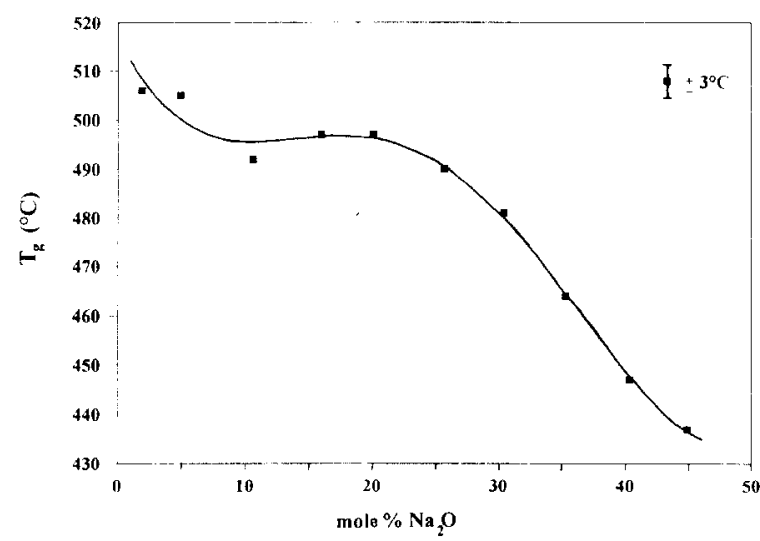

Fig. 7. Glass transition temperatures of the melts in the $\mathrm{Na}_{2} \mathrm{O}$ $\mathrm{SiO}_{2}$ system. reaching a maximum value at $\sim 15$ mole $\% \mathrm{Na}_{2} \mathrm{O}$ (Mazurin et al., 1970; Shelby, 1976).

The $T_{\mathrm{g}}$ data determined in this study compare qualitatively quite well with the systematic determinations from Turner and Winks (1930), and Shelby (1976). A quantitative comparison to the literature data is not appropriate because the measured $T_{\mathrm{g}}$ depends upon both the experimental parameters and the chosen definition of $T_{\mathrm{g}}$. Our data appear to confirm the existence of a local minimum in $T_{\mathrm{g}}$ at $\sim 10$ mole $\% \mathrm{Na}_{2} \mathrm{O}$. Even if the sample with 10 mole $\% \mathrm{Na}_{2} \mathrm{O}$ was partially phase separated an influence of the miscibility gap which occurs at around the same composition (Haller et al., 1974) would not lead to the occurrence of such a minimum. The calorimetrically measured peak temperature does not represent an isokom, a line of constant viscosity. This non-equivalence does not, however, mean that the enthalpic and shear relaxation times of the melts are not equivalent. There are two reasons for this.

(1) The peak temperature is a rough approximation to a constant value of enthalpic relaxation time. In detail, the location of the peak temperature depends on thermal history. The calorimetric measurements are non-linear relaxation measurements on glasses with thermal histories. The existence of the peak is a consequence of mismatch between the fictive temperature of the sample and the glass transition temperature associated with the subsequent heating rate.

(2) The shear relaxation time is not exactly proportional to viscosity, rather it is related through the Maxwell equation by the shear modulus at the temperature of the glass transition.

Thus the shear and enthalpic relaxation times may still be equivalent although the comparison of peak temperature and viscosity does not yield an isokom.

\section{Summary}

These high-precision determinations of the physical properties of supercooled liquids in the $\mathrm{Na}_{2} \mathrm{O}-\mathrm{SiO}_{2}$ system have revealed several impor- 
tant details of the composition- and temperature dependence of melt properties. Volume, thermal expansivity and heat capacity of supercooled liquids in the $\mathrm{Na}_{2} \mathrm{O}-\mathrm{SiO}_{2}$ system are all strongly non-linear functions of composition. The extrapolated values of the partial molar properties of $\mathrm{SiO}_{2}$ confirm anomalous properties for this composition in the supercooled liquid (relaxed) state. Isokoms of the system exhibit an inflection between 20 and 30 mole $\% \mathrm{Na}_{2} \mathrm{O}$ that persists over a $1000^{\circ} \mathrm{C}$ temperature range. The glass transition temperature also exhibits an inflection, at high $\mathrm{SiO}_{2}$ contents. The peak temperatures from scanning calorimetry and dilatometry although identical do not represent an isokom.

\section{Acknowledgements}

We wish to thank Hubert Schulze for the preparation of the samples, Anna Dietel, Gertrud Gollner and Detlef Krauße for the analyses of the sample. This work was supported by DFG grant Di-431/2-1.

\section{References}

Amrhein, E.-M., 1963. Das dielektrische Verhalten binärer Oxydgläser im Mikrowellengebiet zwischen 100 und $900^{\circ}$ C. Glastech. Ber., 36: 425-444.

Bansal, N.P. and Doremus, R.H., 1986. Handbook of Glass Properties. Academic Press, Orlando, Fla., 680 pp.

Bershtein, V.A., Egorov, V.M., Emelyanov, Y.A., Kelina, R.P., Stepanov, V.A. and Cherkas, G.D., 1980. Fiz. Khim. Stekla, 6: 289-299. [In: O.V. Mazurin, M.V. Streltsina and T.P. Shvaiko-Shvaikovskaya (Editors), Handbook of Glass Data, Part A. Elsevier, Amsterdam, 669 pp. (1983).]

Bockris, J.O'M., Tomlinson, J.W. and White, J.L., 1956. The structure of the liquid silicates: partial molar volumes and expansivities. Trans. Faraday Soc., 52: 299-310.

Bottinga, Y. and Weill, D.F., 1970. Density of liquid silicate systems calculated from partial molar volumes of oxide components. Am. J. Sci., 269: 169-182.

Brückner, R., 1970. Properties and structure of vitreous silica, I. J. Non-Cryst. Solids, 5: 123-175.

Dingwell, D.B., 1989a. Effect of fluorine on the viscosity of diopside liquid. Am. Mineral., 74: 333-338.

Dingwell, D.B., 1989b. Shear viscosities of ferrosilicate liquids. Am. Mineral., 74: 1038-1044.
Dingwell, D.B., 1990. Shear viscosities of galliosilicate liquids. Am. Mineral., 75: 1231-1237.

Dingwell, D.B., 1993. Experimental strategies for the determination of granitic melt properties at low temperature. In: J.L.R. Touret and A.B. Thompson (Guest-Editors), Fluid-Rock Interaction in the Deeper Continental Lithosphere. Chem. Geol., 108: 19-30 (special issue).

Dingwell, D.B. and Virgo, D., 1988. Viscosities of melts in the $\mathrm{Na}_{2} \mathrm{O}-\mathrm{FeO}-\mathrm{Fe}_{2} \mathrm{O}_{3}-\mathrm{SiO}_{2}$ system and factors controlling the relative viscosities of fully polymerized silicate melts. Geochim. Cosmochim. Acta, 52: 395-403.

Dingwell, D.B. and Webb, S.L., 1990. Relaxation in silicate melts. Eur. J. Mineral., 2: 427-449.

Dingwell, D.B., Knoche, R., Webb, S.L. and Pichavant, M., 1992. The effect of $\mathrm{B}_{2} \mathrm{O}_{3}$ on the viscosity of haplogranitic liquids. Am. Mineral., 77: 457-461.

Dingwell, D.B., Knoche, R. and Webb, S.L., 1993. The effect of $\mathrm{P}_{2} \mathrm{O}_{5}$ on the viscosity of haplogranitic liquid. Eur. $J$. Mineral., 5: 133-140.

Haller, W., Blackburn, D.H. and Simmons, J.H., 1974. Miscibility gaps in alkali-silicate binaries - data and thermodynamic interpretation. J. Am. Ceram. Soc., 57: 120126.

Knoche, R., Dingwell, D.B. and Webb, S.L., 1992a. Temperature-dependent thermal expansivities of silicate melts: the system anorthite-diopside. Geochim. Cosmochim. Acta, 56: 689-699.

Knoche, R., Dingwell, D.B. and Webb, S.L., 1992b. Non-linear temperature dependence of liquid volumes in the system albite-anorthite-diopside. Contrib. Mineral. Petrol., 111: 61-73.

Knoche, R., Webb, S.L. and Dingwell, D.B., 1992c. A partial molar volume for $\mathrm{B}_{2} \mathrm{O}_{3}$ in haplogranitic melt. Can. Mineral., 30: 561-569.

Lange, R.A. and Carmichael, I.S.E., 1990. Thermodynamic properties of silicate liquids with emphasis on density, thermal expansion and compressibility. Rev. Mineral., 24: 25-64.

Maklad, M.S. and Kreidl, N.J., 1971. Some effects of OH groups on sodium silicate glasses. In: Proceedings of the 9 th International Congress on Glass, Vol. 1, Versailles, pp. $75-100$.

Mazurin, O.V., Roskova, G.P. and Kluyev, V.P., 1970. Properties of phase-separated soda-silica glasses as a means of investigation of their structure. Discuss. Faraday Soc., 50: 191-199.

Mazurin, O.V., Streltsina, M.V. and Shvaiko-Shvaikovskaya, T.P., 1983. Handbook of Glass Data, Part A. Silica Glass and Binary Silicate Glasses. Elsevier, Amsterdam, $669 \mathrm{pp}$.

Moynihan, C.T., Easteal, A.J., Tran, D.C., Wilder, J.A. and Donovan, E.P., 1976. Heat capacity and structure relaxation of mixed-alkali glasses. J. Am. Ceram. Soc., 59: 137140.

Richet, P., 1984. Viscosity and configurational entropy of silicate melts. Geochim. Cosmochim. Acta, 48: 471-483.

Richet, P., 1987. Heat capacity of silicate glasses. In: Y. Bottinga and J.-C. Mathieu (Guest-Editors), Liquid Sili- 
cates. Chem. Geol., 62: 111-124 (special issue).

Richet, P. and Bottinga, Y., 1984. Glass transitions and thermodynamic properties of amorphous $\mathrm{SiO}_{2}, \mathrm{NaAl}-$ $\mathrm{Si}_{n} \mathrm{O}_{2 n+2}$ and $\mathrm{KAlSi}_{3} \mathrm{O}_{8}$. Geochim Cosmochim Acta, 48: 453-470.

Richet, P. and Bottinga, Y., 1986. Thermochemical properties of silicate glasses and liquids: a review. Rev. Geophys., 24: 1-25.

Richet, P., Bottinga, Y. and Tequi, C., 1984. Heat capacity of sodium silicate liquids. Comm. Am. Ceram. Soc., 67: C6C8.

Robie, R.A., Hemingway, B.S. and Fisher, J.R., 1979. Thermodynamic Properties of Minerals and Related Substances at $298.15 \mathrm{~K}$ and 1 bar $\left(10^{5}\right.$ Pascals $)$ Pressure and at Higher Temperatures. U.S. Gov. Print. Off., Washington, D.C., 456 pp.

Samsoen, M.-O., 1926. Sur l'étude dilatométrique et thermique des verres composés de silice et de soude. C.R. Acad. Sci. Paris, 183: 285-286.
Samsoen, M.-O., 1928. Contribution a l'étude de l'état vitreux et de la dilatation des verres. Ann. Phys., Sér., 10: $35-127$.

Shelby, J.E., 1976. Thermal expansion of mixed-alkali silicate glasses. J. Appl. Phys., 47: 4489-4496.

Stebbins, J.F., Carmichael, I.S.E and Moret, L.K., 1984. Heat capacities and entropies of silicate liquids and glasses. Contrib. Mineral. Petrol, 86: 131-148.

Suzuki, S. and Abe, Y., 1981. The free volume of some oxide glasses at the transition temperature. J. Non-Cryst. Solids, 43: 141-143.

Turner, W.E.S. and Winks, F., 1930. The thermal expansion of glass, Part II. Glasses of the series sodium metasilicate-silica. J. Soc. Glass Technol., 14: 110-126.

Webb, S.L., Knoche, R. and Dingwell, D.B., 1992. Determination of silicate liquid thermal expansivity using dilatometry and calorimetry. Eur. J. Mineral., 4: 95-104.

Zallen, R., 1983. The Physics of Amorphous Solids. Wiley, New York, N.Y., 304 pp. 